\title{
Dependency, Satisfaction, and Psycho- Social Characteristics as Correlates of Cell Phone Use by Library and Information Science Undergraduate Students:
}

\author{
Dependency, Satisfaction, and Psycho-Social
} Characteristics as Correlates of Cell Phone Use

\begin{abstract}
Adeyinka Tella, Department of Library and Information Science, University of Ilorin, Nigeria \& Department of
\end{abstract} Information Science, University of South Africa, South Africa

https://orcid.org/0000-0002-5382-4471

\begin{abstract}
The study examined dependency, satisfaction, and psychosocial characteristics as correlates of cell phone use by library and information science (LIS) undergraduate students. Using survey, 253 undergraduates represent the sample for the study. Five research questions were developed and answered. The results of the psychosocial characteristics' correlation with the cell phone use reveal that self-efficacy had the highest correlation with the cell phones use $(r=0.74)$, followed by selfesteem $(r=0.69)$, entertainment $(r=0.37)$, and social interaction $(r=0.33)$. Anxiety had the lowest correlation $(r=0.23)$, but still correlates positively with LIS students' cell phones use. Self-efficacy contributed most to the prediction of LIS students' cell phone use (Beta value $=.299$ ), followed in declining order of strength by dependency $($ Beta $=.292)$, self-esteem $($ Beta $=.182)$, satisfaction (Beta $=.177)$, social interaction $($ Beta $=.111)$, and entertainment $($ Beta $=.106)$.
\end{abstract}

\section{KEYWORDS}

Addiction, Cell Phones, Dependency, Library and Information Science, Psychosocial Characteristics, Satisfaction, Undergraduates

\section{INTRODUCTION}

The last few years have witnessed a dramatic increase in the use of cell phones. Similarly, in recent times there seems to have been a transformation of the cell phone from a status symbol to a necessity because of the countless perks that a mobile phone provides like personal diary, email dispatcher, calculator, video game player, camera and music player (North, Johnston, \& Ophoff, 2014; Comulada, Swendeman, \& Ramanathan, 2018).). Nigeria market has emerged as the first largest market for mobile phone handsets in Africa (Bude.Com, 2014). As Ezemenaka (2013) reported, cell phones are used as part of the conspicuous consumption ritual and also act as a pacifier for the impulsive tendencies 
of the user. Ezemenaka goes further to report that technologic addictions (a subset of behavioral addictions) are no different from substance addictions in that users get some kind of reward from cell phone use, resulting in pleasure. According to Baylor University (2012), cell phones are a part of our consumer culture, as both a tool and a status symbol. They're also eroding our relationships. A majority of young people claim that losing their cell phones would be disastrous to their social lives. Some have even called cell phones "the new cigarettes," seeing as how people fiddle with them in elevators, whip them out as soon as they leave the office, take "cell phone breaks" on the job and chat away while walking, driving, etc. And when your phone isn't ringing, your brain sometimes tricks you into thinking that it is a phenomenon that has been dubbed phantom ringing.

Previous researches (e.g. Thomee, Harenstam, \& Hagberg, 2011; Hong, Chiu, \& Huang, 2012) have shown that young adults are profligate mobile phone users, sending on average 109.5 texts and checking their phones around 60 times in a typical day. However, this disproportionate use is not simply a youthful fad, as a body of evidence has shown that the psychological compulsion behind this excess is very similar to drug addictions (Srinivas \& Fiola, 2013). Increased dependence on mobile technology (e.g., smartphones) has created an even greater neuro-psychological and neuro-social effect on users (Jean \& Park, 2012, Hong, Chiu, \& Huang, 2012, Kwon, 2013, Perlow, 2012). Smartphones, for instance, has become psychological tools that extend the conscious mind in the way we distribute thoughts, memories, exchange information and ideas, and fortify our relationships (Chou, \& Ting, 2012). No doubt, these devices are reliable, yes they are convenient and yes they simplify life. But too much of anything is unhealthy. People have become too dependent on them. In as much as they provide wide and far- reaching advantages, they also have their downsides. People who are addicted to cell phones are more likely to suffer from brain cancer, physical and psychological symptoms, have broken relationships and isolated from the community life (Srinivas \& Faiola, 2014).

Similarly, many people today cannot leave the house without the cell phone, some allude that without their cell phones they feel empty and insecure (Ling, 2004). Thus we are experiencing some form of dependency on the use and possession of cellularphone (Banjo, Hu, \& Sundar, 2008). Essentially, the purpose of cell phones is to make life easier and productive. If one wants to connect/ contact a group of people, one simply goes to the phonebook or opens an email, then selects everyone he wants to share the information with, and right away clicks the send button. Within no minute, they are already on the same page with the sender. This is the beauty of having a cell phone. People have indeed become too dependent on cell phones. In as much as they have improved the quality of life, they have also become an epidemic in modern society. But the problem is not with cell phones. It is people who have taken the devices too seriously. Others depend on it too much. It is ridiculous to see how some people react, for instance, when they lose their cell phones. It's like they have lost the rest of their lives, or the world has come to an end. Others seriously get pissed off, while others it's like they have lost a limb or an equivalent. These are the kind of people that cell phones not only play an integral part in their lives but also central to their whole being (South Good News, 2005). According to 'The World Unplugged Project' (2019), students who seriously depend on their phones cannot afford to stay away from their phones for more than 24 hours. At the end of first day of the research, all the student participants claimed to have developed psychological symptoms, while others displayed physical symptoms (Silk et al., 2009).

It has been reported that the use of mobile phones in schools reduces the concentration of the students during class (Hiscock, 2004; Selwyn, 2003), creates billing problems (Youth Action, 2004), leads to unsafe driving habits (Walsh, White, Hyde, \& Watson, 2008), and causes mobile phone addiction (Ehrenberg, Juckes, White, \& Walsh, 2008). Of all of these outcomes, mobile phone addiction has the strongest relationships with mobile phone usage. However, the researches seem to focus so much on addiction at the expense of dependency. Therefore, examining the psychological antecedents of and the relationships between mobile phone dependency, satisfaction, and mobile phone usage especially among the undergraduates will enhance the understanding of the development mechanism for mobile phone dependency and mobile phone usage behavior. 
This research will probe a segment of a very complex and broad area of consciousness research. While psychologists propose possible reasons for smartphone addiction owing to its ability to alter mood and trigger enjoyable feelings, it is not fully known if repetition of use and dependency is correlated to satisfaction and psychological factors such as self-concept, interaction, and anxiety. Hence, this study aims to identify smartphone dependency and its relationship to satisfaction and psychological characteristics or factors. Based on this, the research aimed to find out whether or not cell phone use creates dependency and identify the way it relates to satisfaction and psychosocial characteristics. Though studies such as this and its findings may not be new in some advanced countries. However, it is of significance to African countries particularly Nigeria and the population of Library and Information Science students because it reveals the adverse effects of dependency on cell phones and how it drift attention and concentration of students away from their learning. The outcomes is expected to enable LIS students to re-adjust so as not to be negatively affected.

This study is considered significant in view of the fact that it will assist communities to stay socially active maintaining interpersonal relationships and therefore enriching the social capital (Chou \& Hsiao, 2000). Healthy social interaction helps one maintain good physical and emotional health and cognitive function (Lloyd \& Devine, 2009). Although social interaction is complex, it is vital to human health, both mentally and physically. It provides many learning opportunities (Roos, 2003). University undergraduate, who learn appropriate social interaction skills often have higher self-esteem, self-concept and show a greater willingness to interact with their peers and environment (Reid \& Reid, 2007).

\subsection{Objectives of the Study}

The main objective of this study is to examine dependency, satisfaction and psychosocial characteristics as correlates of cell phone use by LIS undergraduate students.

The specific objectives are to:

1. Determine the correlation between dependency and use of cell phones by LIS undergraduate students.

2. Find out whether there is a correlation between LIS UG satisfaction and the use of cell phones.

3. Determine the correlations between LIS UG psychosocial characteristics/factors and the use of cell phones.

\subsection{Research Questions}

To achieve the stated objectives, the following research questions will be answered by the study:

1. What correlation exists between cell phone use, dependency, satisfaction and psychosocial characteristics of LIS undergraduate students?

2. What is the correlation between the heavy use of cell phones and dependency by LIS undergraduate students?

3. Is there a correlation between LIS UG satisfaction and the use of cell phones?

4. Which of the psychosocial characteristics will determine dependency on the cell phones by the LIS UG students?

\section{LITERATURE REVIEW}

\subsection{Cell Phone Use}

A cell phone is a portable wireless electronic device used to but not limited to communicate, socialize, and entertain. It is also referred to as a mobile phone. A mobile phone (also known as a cellular 
phone, cell phone, and a handphone) is a phone that can make and receive telephone calls over a radio link while moving around a wide geographic area. It does so by connecting to a cellular network provided by a mobile phone operator, allowing access to the public telephone network (Chatterjee, 2014). Application of the cell phone as a tool includes talking, text messaging, game playing or the sheer accessibility of the instrument (Banjo, Hu \& Sundar, 2008). By contrast, a cordless telephone is used only within the short range of a single, private base station. In addition to telephony, modern mobile phones also support a wide variety of other services such as text messaging, MMS, email, Internet access, short-range wireless communications (infrared, Bluetooth), business applications, gaming, and photography. Mobile phones that offer these and more general computing capabilities are referred to as Smartphones (Chatterjee, 2014). It can be said that the cultural meaning of the mobile phone has moved beyond that of a simple tool or appliance. Originally, the cell phone served as a tool for business management. Now, cell phones serve as a tool for social connection, in other words, managing social relationships.

\subsection{Cell Phone Dependency}

Research tends to show that internet overuse behavior does not necessarily produce addiction, but if addiction is present, internet usage will markedly increase. Mobile phone usage belongs to the same interactive technology like the internet, and should therefore, have a similar impact. This study investigates whether the greater use of mobile phones increase the instance of mobile phone addiction and attendant problems.

Research shows that mobile phone addiction is significantly correlated with the total of phonetalk time, and the number of calls and text messages (Billieux et al., 2008; Billieux, 2012). Currently used measures to investigate the behavior of mobile phone mainly assess the number of calls made and text messages sent (Walsh et al., 2011), however, it is clear that these features do not themselves signal mobile phone dependency which eventually results to addition (Walsh et al., 2011). The current study considers the need for further analysis of the relationship between mobile phone usage and mobile phone dependency to clarify the mediation process of mobile phone dependency upon mobile phone usage.

\subsection{Psychosocial Characteristics}

In addition to identifying the possible mobile phone usage patterns of university students with addiction, it is also important to identify the individual's inner psychological characteristics that affect mobile phone usage. Because the reason why young people use mobile phones could relate to selfidentity, improving one's status compared to peers, and enhancing a sense of security, entertainment, social relationships and interpersonal interaction (Hong and Huang, 2012). This phenomenon is more likely to be contributed by the psychological characteristics of individuals (Butt \& Phillips, 2008). This study, therefore, explored factors such as university students' psychological characteristics of anxiety, self-esteem and their effect on mobile phone usage.

\subsubsection{Self- Esteem}

It has been perceived long ago that young people's self-esteem is associated with peer relationships (Augner et al., 2012), especially if their self-worth is linked to approval from others (Billieux, 2012). When the mobile phone can provide links with others, self-esteem may affect mobile phone use behavior. People with low self-esteem more frequently make calls and send more text messages (Pundir et al., 2016). Contrarily, other researchers have reported no relationship between self-esteem and the levels of usage of mobile phones (Butt \& Phillips, 2008; Ehrenberg et al., 2008). These indicate that the relationship between self-esteem and mobile phone usage behavior needs to be clarified by additional exploratory analysis.

Mobile phone ownership may, in this way, play an important role in subgroup culture and, in turn, self-esteem. Self-esteem has consistently been linked to dependency and eventually addictive 
behavior (Billieux, 2012). Yang, Yen, Hung, Cheng, and Yen (2010) theorizes that low self-esteem may cause people to behave in ways that are self-defeating to escape self-awareness. Mobile phones may be addictive if used as a form of escape from situations that the user finds aversive. Based on the literature related to self-esteem and dependency, it is expected in this study that higher and problematic use of mobile phones can be predicted by low self-esteem.

\subsubsection{Cell Phone Use Self-Efficacy}

Self-efficacy implies an individual's level of belief that he or she can organize and perform a series of activities intended to achieve a result (Bandura, 1997). Self-efficacy is a major factor affecting attitude and behavior. Self-efficacy represents an individual's judgment that he or she can complete a specific task, and is unconnected with the individual's actual skills. An individual's perceived self-efficacy will affect his or her person's behavior towards a specific task, amount of mental effort, and degree of persistence, and will ultimately influence the individual's actions (Bandura, 1997; Gunther., \& Barkley \& Lepp, 2013). It is assumed that persons with strong cell phone self-efficacy will tend to use cell phones frequently, and will tend not to experience cell phone anxiety. Relevant empirical research has indicated that computer software self-efficacy, Internet use self-efficacy, and online income tax reporting self-efficacy will all influence attitude towards using these technological applications (Lepp et al., 2015; Tsang, Shu-Chun Ho, Ting-Peng Liang, 2004). Therefore, it is anticipated in this study that high mobile phone self-efficacy will increase mobile phone use.

\subsubsection{Anxiety}

People with higher social anxiety scores tend not to overuse mobile phones in voice-calling (Gao et al., 2016); rather they spend more time in indirect communication through text messaging with others (Billieux et al., 2008; Butt\& Phillips, 2008, Alan, 2016). Lepp, Barkley, and Karpinski (2015) in their study on Students' Frequency of cell phone use anxiety, lower grade and happiness showed that cell phone use by college students was negatively related to GPA and positively related to anxiety. Following this, GPA was positively related to happiness while anxiety was negatively related to happiness. Thus, for the population studied, high-frequency cell phone users tended to have higher anxiety, and lower satisfaction with life (happiness) relative to their peers who used the cell phone less often. In light of this, this study explored the relationship between anxiety and mobile phone use behaviors.

\subsubsection{Social Interaction}

Social interaction signifies that we are aware of the existence of others, as well as implies active engagement between two or more parties (Banjo, Hu, \& Sundar, 2008, Ictech, 2014). Social interaction refers to how people communicate, relate, connect, make exchanges and make contacts. Social interactions are the acts, actions, or practices of two or more people mutually oriented towards each other's selves, that is, any behavior that tries to affect or take account of each other's subjective experiences or intentions. This means that the parties to the social interaction must be aware of each other and have each other's self in mind. Learning for any child begins at home through the socialization process. Engagement with the mobile phone disconnected people from physical connections and copresent activities and activities occurring around them (de Gournay, 2002, Matic et al., 2012). The mobile phone has found its way into many homes with children as early as eight (8) years owning and using mobile phones (Lenhart \& Campbell, 2010). This development is assumed to have an impact on their social interactions (Gergen, 2002; Matic et al. 2012).

Too much dependency on the cell phones can prevent an individual from making new friends and noticing small details in everyday life (Boase \& Ling, 2013). According to Banjo and Sundar (2008; Rainie \& Zickuhr, 2015), the concept of being accessible anywhere and anytime has been found to have both positives and negative results in a social setting. It is on this note, that, this current study 
intends to find out whether or not social interaction which is one of the factors of social characteristics will have a relationship with cell phone use.

\subsubsection{Entertainment}

According to McQuail (1983), the value of entertainment lies in its ability to satisfy consumers'/ users' desire to escape reality and obtain fun and emotional release. When users interact with media, a high degree of enjoyment and involvement will consequently have a positive effect on subjective perception and mood (Hoffman \& Novak, 1996). Brackett and Carr, (2001), Ken State University (2011), believe that entertainment is a key factor associated with mobile use, and suggests that the content of messages must be concise and interesting to induce immediate attention in users. The perception of the feeling that using cell phones is interesting will affect users' attitudes and increase use. In light of this, it is assumed in this study, that the more users perceive mobile phone use to be entertaining, the better their use and attitude towards it.

From the extant review of literature, studies have consistently shown that there are significant relationships between, high anxiety, and low self-esteem with mobile phone dependency (Bianchi \& Phillips, 2005, Billieux, 2012), and the stronger the young person's mobile phone dependency, the more likely the individual has high mobile phone call time, an excessive number of calls and text messages (Billieux et al., 2008; Pundir et al. 2016; Gao et al., 2016). These findings suggest that the effect of self-esteem, social interaction, and anxiety on young people's mobile behavior may be mediated by dependency variables. On this note, this study explored the relationship between psychosocial characteristics and mobile phone usage behavior to improve the understanding of the role played by mobile phone dependency on the university students' mobile phone usage.

\section{MATERIAL AND METHODS}

\subsection{Research Design}

The design adopted for this research is a survey. A survey is a data collection tool used to gather information about individuals. Surveys are commonly used in LIS research to collect self-report data from study participants. A survey may focus on factual information about individuals, or it might aim to collect the opinions of the survey takers. This design gives room for the researcher to cover a substantial percentage of respondents (students) in the universities/departments that were covered in the study. The survey design method was adopted because it has been prominently used in previous related studies (e.g. Butt \& Sham, 2013; Li, 2012; Ezemenaka, 2013).

\subsection{Area of the Study}

The study covered two departments from two different universities. The departments are Library and Information Science at the University of Ilorin, Nigeria and Kwara State University Malete, Ilorin, Nigeria. The two departments were chosen because the study focused on the Library and Information Science undergraduates' students and it is only these universities that are running a bachelor degree in Library and Information Science among the universities in Kwara State, Nigeria at the time the study was conducted.

\subsection{Population and Sample}

The population for the study includes all the male and female year 2-4 undergraduates' students from the two selected departments in the two universities. The total enumerative sample method was adopted. This was due to the small size of the populations of students in the participating departments. A total enumeration is a study of every unit, everyone, or everything, in a population. It is known as a total enumeration, which means a complete count. According to Babbie (2013), if a study population is small and less in number, it may be preferable to do a census of everyone in the population, rather 
than a sample. A census is attractive for small populations necessary for given combinations of precision, confidence levels, and variability (Kothari, 2013; Creswell, 2014; Creswell \& Creswell, 2017 ; 2018). This approach has a high level of accuracy and provides complete statistical coverage over space and time. In other words, the researcher sampled all the undergraduates' students in the two departments covered by the study. The sample size obtained amounted to (253) i.e. 113 from the Department of LIS, University of Ilorin and (140) from the Kwara State University, Malete, Ilorin. This represents the sample for this study (See Table 1).

\subsection{Research Instrument}

The research instrument used for data collection in the study was a questionnaire whose items were adapted from various previous relevant studies. This was used to gather in-depth information desired. The questionnaire was a closed-ended type. The questionnaire was divided into two sections, section one consists of demographic characteristics of the respondents. Section two was sub-divided into parts A, B, C, D, E, F,G, H with each part targeted at capturing data on the variables focused in the study of Cell Phone Use, Dependency, Satisfaction and the Psychosocial characteristics (Self-esteem, Anxiety, Social Interaction, Entertainment, and Self-Efficacy). The Coppersmith (1967) Self Esteem Inventory (SEI) is a 50-item questionnaire, designed to measure evaluative attitudes toward the self in social, academic, family, and personal areas of experience were adapted. The 50-item SEI was modified and reduced to 10 items. This was used in this research to gather data on self-esteem. Mobile phone anxiety items were adapted from Walsh (2012) scale. It consisted of ten items with a 5-point response format having a 0.82 reliability coefficient. Social interaction was measured by 10 items questionnaire. The items from this sub-section were derived from the literature with 5-point response format and a reliability coefficient of $r=0.78$. The scale used for measuring cell phone self-efficacy was adapted from Lee et al., (2011) Mobile Self-Efficacy Questionnaire. This scale consisted of 10 items measured on a five-point Likert type scale (from $1=$ very low to $5=$ very high), the ten items scale return an $r=0.78$ Cronbach Alpha reliability. A modified scale for measuring entertainment was also adapted from Lee et al (2011) mobile self-efficacy questionnaire. This scale consisted of 10 items measured on a five-point Likert type scale (from $1=$ very low to $5=$ very high), the ten items scale return an $r=0.80$ Cronbach Alpha reliability. Users' satisfaction with mobile phones was measured using the Mobile Phone Satisfaction scale. This variable measured satisfaction with mobile phones, consisting of items generated from the Dobrota et al (2012) mobile phone satisfaction questionnaire. The questionnaire adopted a 5-point Likert scale. It consisted of ten items construct. A Cronbach's alpha coefficient for internal consistency of the scale returned an $r=0.87$, indicating that it possesses a good internal consistency (Cronbach, 1951; George and Mallery, 2003). Mobile phone dependency items with an item such as ("I neglect school assignment to spend more time using a mobile phone") were adapted from Mobile Phone Addiction Scale by Hong et al. (2012) with a reliability of 0.80. Also, ten items measuring cell phone use was developed from the literature returning an $r=0.83$. The entire questionnaire consisted of 40 items. Each item was scored on a five-point Likert scale ranging (from $1=$ strongly disagree to $5=$ strongly agree) and (from $1=$ very low to $5=$ very high). The overall reliability coefficient of the whole 40 items instrument reported an $r=0.93$ Cronbach's alpha. This is high enough in some way thereby confirming the instrument as adequate for this study.

\subsection{Procedure for Data Collection}

The researcher personally administered the questionnaire to the respondents and with the help of the class representative in each of the departments. The instructions given to the respondents at the commencement of the administration made the exercise very easy. The exercise was carried out on six different occasions with each occasion targeting/capturing data from each level of study. Out of the (253) copies of the questionnaire administered based on the sample, the entire (253) copies were returned, properly filled, completed and useful for data analysis. This gives a $100 \%$ return rate. 
Table 1. Demographic distribution of respondents $(\mathrm{N}=)$

\begin{tabular}{|l|l|l|}
\hline \multicolumn{1}{|c|}{ Demographics } & Frequency & \\
\hline Gender & & Percent \% \\
\hline Male & 111 & 43.9 \\
\hline Female & 142 & 56.1 \\
\hline Total & 253 & 100.0 \\
\hline Age & & \\
\hline $17-25$ years & 141 & 55.7 \\
\hline $26-30$ years & 99 & 39.1 \\
\hline $31-35$ years & 10 & 4.0 \\
\hline 36 years + & 3 & 1.2 \\
\hline Total & 253 & 100.0 \\
\hline Institution & & \\
\hline LIS Department Uni. Of Ilorin & 113 & 44.7 \\
\hline LIS Department, KWASU & 140 & 55.3 \\
\hline Level of Study & & \\
\hline 200 Level (Year 1) & 77 & 30.4 \\
\hline 300 Level (Year 2) & 84 & 33.2 \\
\hline 400 Level (Year 4) & 92 & 36.4 \\
\hline Total & 253 & 100.0 \\
\hline & & \\
\hline
\end{tabular}

\subsection{Method of Data Analysis}

Descriptive and inferential statistics including percentage, correlation, and multiple regression analysis methods were used to analyze the data. Pearson correlation method was used to examine the relationships between the dependent variables (cell phone and dependency) with the independent variables (i.e. satisfaction, and psychosocial characteristics i.e. self-esteem, anxiety, social interaction, and entertainment) while regression analysis was used to find out the contribution of the independent variables to the dependent variables. A statistical package for social science (SPSS) version 20 for Windows was used for the coding of the collected data.

\section{RESULTS}

Table 1 reveals the demographic information of the respondents. The result shows that 140 respondents (55.3\%) were students from LIS Department, Kwara State University, Malete, Ilorin, Nigeria while respondents who are students from the Department of Library and Information Science University of Ilorin, Nigeria were $113(44.7 \%)$. The results on the gender variable of the respondents reveal that $50 \%$ were male and $50 \%$ were female. The result on the age of the respondents shows that those between ages 17-25 years were 141 (55.7\%) which of course represents the majority of the respondents. Those between the age range of 26-30years were 99 (39.1\%) and those ages 31-35 years were $10(4.0 \%)$ and those ages 36 years and above were 3 representing (1.2\%).

Table 2 reveals that inter-correlation exists between the overall cell phone use score and the other related factors/measures. The results show that cell phone dependency had the highest correlation with cell phone use $(r=0.77)$. This is followed by cell phone satisfaction $(r=0.75)$. The results of 
Table 2. Descriptive Statistics and Inter-correlation Matrix among Factors (N=253)

\begin{tabular}{|c|c|c|c|c|c|c|c|c|c|c|}
\hline \multirow{2}{*}{ Factors (Variables) } & \multirow{2}{*}{ Mean } & \multirow{2}{*}{$\begin{array}{l}\text { Std. } \\
\text { Dev. }\end{array}$} & \multicolumn{8}{|c|}{ Factors (Variables) } \\
\hline & & & (1) & (2) & (3) & A & B & $\mathrm{C}$ & D & $\mathbf{E}$ \\
\hline (1) Cell Phone Use & 108.8544 & 26.942 & 1.000 & & & & & & & \\
\hline (2) Dependency & 16.894 & 3.852 & .769 & 1.000 & & & & & & \\
\hline (3) Satisfaction & 10.189 & 2.685 & .752 & -0.008 & 1.000 & & & & & \\
\hline $\begin{array}{l}\text { (4) Psycho } \\
\text { a. Self-Esteem }\end{array}$ & 8.611 & 2.478 & .691 & .330 & .434 & 1.000 & & & & \\
\hline b. Self-Efficacy & 6.441 & 2.224 & .736 & .354 & .300 & .211 & 1.000 & & & \\
\hline c. Anxiety & 2.111 & 1.256 & .225 & -.122. & -.309 & -.119 & -.101 & 1.000 & & \\
\hline d. Social Interaction & 6.022 & 2.121 & .333 & .227 & .305 & .177 & .314. & .322 & 1.000 & \\
\hline e. Entertainment & 6.001 & 2.119 & .373 & .229 & .311 & .155 & .234 & .201 & .199 & 1.000 \\
\hline
\end{tabular}

the psychosocial characteristics correlation with the cell phones use reveal that self-efficacy had the highest correlation with the cell phones use $(r=0.74)$, followed by self-esteem $(r=0.69)$, entertainment $(\mathrm{r}=0.37)$ and social interaction $(\mathrm{r}=0.33)$ in that order. Anxiety had the lowest correlation with $(\mathrm{r}$ $=0.23$ ) but still correlate positively with LIS students' cell phones use.

Table 3 (a-c) shows the regression of LIS Students' Cell Phone Use, Dependency, Satisfaction and Psychological Characteristics $(\mathrm{N}=253)$.

Table 3 presents the results of the regression of cell phones use factors and the five psychosocial characteristics factors. The regression results show an adjusted R-square value of 0.523 Table $3(\mathrm{a})$, and an F-ratio of 80.24 (Table 3(b), the latter of which is significant at 0.05 level $(0.000<0.05)$. These results indicate that the two independent variables (cell phone dependency and satisfaction), together with the five psychosocial characteristics jointly (as indicated by the R-square value) explained or predicted $56 \%$ of the variations in the LIS students' cell phones use. The prediction is also significant, as indicated by the F-ratio.

Table 3(c) provide information on the individual contributions of each of the two factors with the five psychosocial characteristics in predicting LIS students' cell phone. The results show, firstly, that each of the factors makes significant contributions to the prediction (as indicated by the significance

Table 3a. Model summary

\begin{tabular}{|l|l|}
\hline Multiple R & .742 \\
\hline R Square & .555 \\
\hline Adjusted R Square & .523 \\
\hline Std. Error of the Estimate & 4.432 \\
\hline Log-likelihood Function Value & -160.514 \\
\hline
\end{tabular}

Table 3b. ANOVA

\begin{tabular}{|l|l|l|l|l|l|}
\hline & Sum of Squares & \multicolumn{1}{|c|}{ Df } & Mean Square & \multicolumn{1}{c|}{ F } & Sig. \\
\hline Regression & 32477.229 & 8 & 4059.654 & 80.24 & .000 \\
\hline Residual & 12396.292 & 245 & 50.597 & & \\
\hline Total & 44873.521 & 253 & & & \\
\hline
\end{tabular}


Table 3c. Coefficients

\begin{tabular}{|c|c|c|c|c|c|c|}
\hline & \multicolumn{2}{|c|}{$\begin{array}{l}\text { Unstandardized } \\
\text { Coefficients }\end{array}$} & \multicolumn{2}{|c|}{$\begin{array}{c}\text { Standardized } \\
\text { Coefficients }\end{array}$} & \multirow[b]{2}{*}{$\mathbf{T}$} & \multirow[b]{2}{*}{ Sig. } \\
\hline & B & Std. Error & Beta & Std. Error & & \\
\hline (Constant) & -.884 & .775 & & & -.895 & 0.05 \\
\hline Dependency & .676 & .083 & .292 & .088 & 7.455 & 0.05 \\
\hline Satisfaction & .385 & .073 & .177 & .060 & 6.003 & 0.05 \\
\hline $\begin{array}{l}\text { Psychosocial: } \\
\text { Self-esteem }\end{array}$ & .325 & .061 & .186 & .052 & 6.751 & 0.05 \\
\hline Self-efficacy & .300 & .057 & .299 & 0.47 & 6.891 & 0.05 \\
\hline Anxiety & .112 & .023 & .018 & 0.06 & 2.331 & 0.05 \\
\hline Social Interaction & .244 & .051 & .111 & 0.41 & 6.245 & 0.05 \\
\hline Entertainment & .266 & .049 & .106 & 0.39 & 6.311 & 0.05 \\
\hline
\end{tabular}

of the $t$ values, which are higher than 0.05 , as shown in the ' $t$ ' column of the table. Anxiety $(t=2.33)$ made a lower contribution to cell phone use but despite its lower value, its correlation is still positive.

Secondly, the standardised coefficients (Beta values) which indicate relative strength of each factor in the prediction of cell phones use show that self-efficacy contributed most to the prediction of LIS students cell phones use (Beta value $=.299$ ), followed in declining order of strength by dependency $($ Beta $=.292)$, self-esteem $($ Beta $=.182)$, satisfaction $($ Beta $=.177)$, social interaction $($ Beta $=.111)$ and entertainment $($ Beta $=.106)$. Although anxiety had a Beta value of .018 , its contribution is not significant, as indicated in the final column (Sig. less than 0.05). These results imply that the two original factors (dependency and satisfaction) and five psychosocial factors exert significant contributions to explain or predict LIS students' cell phones use.

Table 4 shows the correlation between LIS students' cell phone dependency and cell phone use. The data show the absolute $\mathrm{r}$. value equal to 0.98 and $\mathrm{P}<0.05$. This is considered a positive correlation. This means that the two variables have a strong tendency to vary together. This indicates that there is a significant correlation or relationship between LIS students' cell phone dependency and cell phone use.

Table 5 shows the correlation between LIS students' satisfaction and the use of cell phones based on 253 respondents. The data show the absolute $\mathrm{r}$. value equal to 0.81 and $\mathrm{P}<0.05$. This is considered a positive correlation. It's implies that the two variables tend to vary together. This indicates that there is a significant correlation or relationship between LIS students' satisfaction and the use of cell phones.

Also, the cell phone dependency was taken as the dependent variable, correlated and regressed with the five psychosocial characteristics - self-esteem, self-efficacy, anxiety, social interaction, and entertainment as independent variables in the model, the result obtained is presented as shown in Tables $6(\mathrm{a}-\mathrm{c})$.

Table 6 a presents the results of the regression of the five factors/variables psychosocial character -tics with cell phone dependency. The regression results show an adjusted R-square value of 0.445

Table 4. Correlation between LIS Students' Cell Phones Dependency and Use of Cell Phones ( $\mathrm{N}=253$ )

\begin{tabular}{|l|l|l|l|l|l|}
\hline \multicolumn{1}{|c|}{ No. } & \multicolumn{1}{|c|}{ Mean } & \multicolumn{1}{c|}{ SD } & \multicolumn{1}{c|}{ R } & P & Decision \\
\hline 253 & 30.94 & 24.90 & 0.98 & 0.05 & S*** \\
\hline 253 & 29.89 & 24.48 & & & \\
\hline
\end{tabular}


Table 5. Correlation between LIS Students' Satisfaction and Use of Cell Phones ( $=253$ )

\begin{tabular}{|l|l|l|l|l|l|}
\hline \multicolumn{1}{|c|}{ No. } & \multicolumn{1}{|c|}{ Mean } & \multicolumn{1}{c|}{ SD } & \multicolumn{1}{c|}{ R } & \multicolumn{1}{c|}{ P } & Decision \\
\hline 253 & 28.43 & 18.94 & 0.81 & 0.05 & NS \\
\hline 253 & 29.45 & 22.47 & & & \\
\hline
\end{tabular}

Table 6a. Model summary of the Extent of the Independent Factors contribution to Cell Phones Dependency (N=253)

\begin{tabular}{|l|l|l|l|l|}
\hline Model & \multicolumn{1}{|c|}{$\mathbf{R}$} & \multicolumn{1}{|c|}{ R Square } & Adjusted R Square & Std. Error of the Estimate \\
\hline 1 & $.191(\mathrm{a})$ & .756 & .445 & 5.743367 \\
\hline
\end{tabular}

a. Predictors: (Constant), self-esteem, self-efficacy, anxiety, social interaction, entertainment

Table 6b. ANOVA on the Factors Contribution to the Cell Phones Dependency

\begin{tabular}{|l|l|l|l|l|l|l|}
\hline \multicolumn{2}{|c|}{ Model } & $\begin{array}{c}\text { Sum of } \\
\text { Squares }\end{array}$ & \multicolumn{1}{|c|}{ Df } & Mean Square & F & Sig. \\
\hline 1 & Regression & 901.555 & 5 & 180.311 & 5.75 & $.003(\mathrm{a})$ \\
\hline & Residual & 7678.790 & 245 & 31.34 & & \\
\hline & Total & $8,580.345$ & 253 & & & \\
\hline
\end{tabular}

a. Predictors: (Constant), self-esteem, self-efficacy, anxiety, social interaction, entertainment

Table 6c. Co- efficient of the Factors Contribution to Cell Phone Dependency

\begin{tabular}{|c|c|c|c|c|c|}
\hline & \multicolumn{2}{|c|}{ Unstandardised Co-efficient } & \multicolumn{2}{|c|}{$\begin{array}{c}\text { Standardised } \\
\text { Co-efficient }\end{array}$} & \multirow[t]{2}{*}{ Sign. } \\
\hline & B & Std. Error & Beta & $\mathbf{T}$ & \\
\hline (Constant) & 23.651 & .966 & .354 & $11 . .315$ & 0.05 \\
\hline Self-esteem & .299 & .128 & .440 & 2.435 & 0.05 \\
\hline Self-efficacy & -.281 & .130 & .271 & 3.508 & 0.05 \\
\hline Anxiety & -.622 & .378 & .322 & 2.405 & 0.05 \\
\hline Social Interaction & -.222 & .152 & .345 & 2.085 & 0.05 \\
\hline Entertainment & .289 & .211 & & 3.718 & 0.05 \\
\hline
\end{tabular}

a. Dependent Variable: Cell Phones Dependency

Table 6(a), and an F-ratio of 5.75 (Table 5(b), the latter of which is significant at 0.05 level $(0.000$ $<0.05$ ). These results indicate that the five independent variables/factors (self-esteem, self-efficacy, anxiety, social interaction, entertainment) jointly (as indicated by the R-square value) explained or determine $75 \%$ of the variations in the LIS students' cell phones dependency. This is also significant, as indicated by the F-ratio.

Table 6(c) provides information on the individual contributions of each of the model psychosocial characteristics in predicting cell phone dependency. The results show that, the entire five factors make significant contributions to the prediction of LIS students' cell dependency as indicated by the significance of the $t$ values, which are greater than 0.05 , as shown in the ' $t$ ' column of the table.

Moreover, the standardised coefficients (Beta values) which indicate relative strength of each factor in the prediction of cell phones dependency show that self-efficacy contributed most to the prediction of LIS students' cell phone dependency (Beta value $=.440$ ), followed in declining order 
of strength by self-esteem $($ Beta $=.354)$, entertainment $($ Beta $=.345)$, social interaction $($ Beta $=$ .322 ) and Anxiety $($ Beta $=.271)$. These results imply that the five factors exert a higher significant contribution to the prediction of LIS students' cell phone dependency.

\section{DISCUSSION}

The first results in this study revealed that cell phone dependency had the highest correlation with cell phone use followed by cell phones satisfaction. No doubt, it has earlier been postulated that mobile phones are becoming an important part of the younger peoples' culture (Charlton, Panting, \& Hannan, 2002). As it was argued, mobile phone ownership in this way, play an important role in subgroup culture and, in turn, self-esteem. This result is corroborated by the postulation that self-esteem has consistently been linked to dependent behavior (Marlatt., Baer, Donovan, 1988; Yang et al. 2010; Augner, 2012) and the addictive behavior in that context is likened to cell phone dependency in the current study. The finding is also in support of (Billieux et al.,2008; Billieux, 2012) results that stated, the stronger the young person's mobile phone dependency, the more likely is that individual to have high mobile phone call time, an excessive number of calls and text messages.

The results of the psychosocial characteristics correlation with the cell phones use reveal that selfefficacy had the highest correlation with the cell phones use followed by self-esteem, entertainment, and social interaction. Anxiety had the lowest correlation but still correlates positively with LIS students' cell phones use. It has been observed from the literature that many factors determine dependency on cell phones and the results of this study have demonstrated just that. Therefore, having factors like satisfaction, dependency, self-esteem and efficacy, anxiety, social interaction and entertainment correlated with cell phones use in this study is not a coincidence. This is because self-efficacy, for instance, has been considered a major factor affecting attitude and behavior. This means the higher it is, the higher that behavior. Similarly, Pundir et al., (2016) and Barkley and Lepp (2013) position, which stated that, 'low self-esteem may cause people to behave in ways that are self-defeating to escape self-awareness and as a result resort to addictive use of mobile phones as a form of escape from situations that the user finds aversive' also lend credence to this current finding. Lepp, Barkley, and Karpinski (2014) report that cell phone use by college students positively related to anxiety also supports the finding on cell phone use and anxiety. This means that, higher anxiety leads to the high use of cell phones.

There is a significant correlation or relationship between LIS students' cell phone dependency and cell phone use and correlation or relationship between LIS students' satisfaction and use of cell phones. Based on this result, it can be said that it is common especially as far as the use of technology is concern that, the moment the users are satisfied with a particular technology, the high use of that technology is always usually the result. The finding in this study is not an exception because the cell phone is a technology, therefore, the satisfaction derived from using it by the LIS students might be responsible for its use by them. Moreover, whatever an individual depends on will be relied on and thereby result to its consultation and use from time to time; hence, the correlation of cell phone dependency and cell phone use reported in this study is also not a coincidence.

The five factors (self-esteem, self-efficacy, anxiety, social interaction, entertainment) exert a higher significant contribution to the determinant of LIS students' cell phone dependency. There is no doubt, the fact that psychosocial characteristics like self-esteem, self-efficacy, anxiety and social interaction and entertainment can reduce but increase dependency on cell phones. This is because the LIS students will always want to boost their self-esteem and never want to be self-defeated. In the same vein, their self-efficacy in the use of cell phones will always push and prompt them to use cell phones every time and by so doing result in being dependent on it. Moreover, since students will always like to bail themselves out of the anxious situations, they resort to depending on a cell phone. At the same time, majority of them want to interact and be like their peers who relies mostly on cell phones for social interaction thereby corroborating what (Banjo, Hu, \& Sundar, 2008; Ictech, 2014; 
Matic et al. 2012) put forward that we are aware of the existence of others by making use of cell phones for social interaction. This is as well implies active engagement between two or more parties. People entertain themselves, especially when faced with an ugly situation. This is in line with (Lee, Hsieh, \&Huan, 2011) proposition that the source of satisfaction is entertainment. Similarly, (McQuail, 1983; Brody et al. 2017) position that the value of entertainment lies in its ability to satisfy users' desire to escape reality and obtain fun and emotional release; and, the statement which stated, that, when users interact with media, a high degree of enjoyment and involvement will consequently have a positive effect on subjective perception and mood made by (Ken State, 2011) and (Brody et al. 2017) believe, that entertainment is key factor associated with mobile use; are all in good support of this current finding.

\section{CONCLUSION}

The first results in this study revealed that cell phone dependency had the highest correlation with cell phone use followed by cell phone satisfaction. The results of the psychosocial characteristics correlation with the cell phones use revealed that self-efficacy had the highest correlation with the cell phone use followed by self-esteem, entertainment, and social interaction in that order. Anxiety had the lowest correlation but still correlate positively with LIS students' cell phones use. Self-efficacy contributed most to the prediction of LIS students' cell phone use to follow in declining order of strength by dependency, self-esteem, satisfaction, social interaction, and entertainment. Dependency and satisfaction and five psychosocial factors (self-esteem, self-efficacy, anxiety, social interaction, and entertainment) exert significant contribution to the prediction of LIS students' cell phone use. There is a significant correlation or relationship between LIS students' cell phone dependency and cell phone use and correlation or relationship between LIS students' satisfaction and use of cell phones. The five factors (self-esteem, self-efficacy, anxiety, social interaction, entertainment) exert a higher significant contribution to the prediction of LIS students' cell phone dependency.

Therefore, it is generally concluded that the higher each of the psychosocial characteristics, the higher the cell phones use and dependency on a cell phone by LIS undergraduate students, however; it is only anxiety that can lower the use and dependency on cell phone by LIS undergraduate students.

\section{RECOMMENDATIONS}

Dependency on cell phones has been reported related to cell phones use by LIS students in this study. However, this is considered detrimental because it has been reported in the literature by Lepp, Barkley, and Karpinski (2014) that dependency on cell phones negatively affects students' GPA. In light of this, LIS students are encouraged to desist from the act of over-dependent on cell phones which can have a debilitating effect on their GPA. However, more attention can be diverted to academic-related activities than depending on cell phones.

Cell phones provide fast and immediate access to academic-related information, this might be the reason why many LIS undergraduates depend on them. However, over-dependent which results in damages of other academic activities when in school should be discouraged.

Finally, as noted in this study, psychosocial characteristics were revealed as having a correlation with cell phone use. Self-esteem influenced participants' mobile phone use. Self-efficacy, entertainment, social interaction, and anxiety directly affect participants' level of mobile phone use and involvement. Therefore, further research, possibly using qualitative methods, could be considered to explore the relationship between these factors on undergraduates' mobile phone use behavior in greater depth. Additionally, dependency and mobile phone use were revealed to be related, but they are separate constructs. Further research is required to explore the developmental trajectory and the relationship between the behaviours. 


\section{COMPLIANCE WITH ETHICAL STANDARDS}

This serves to disclose that there is no potential conflict of interest or whatsoever whether financial or non-financial as far as this research is concerned. The research is based on dependency, satisfaction and psychosocial characteristics as correlates of cell phones use by library and information science (LIS) undergraduate students. It is a pure research effort solely financed by the author.

The research involved human beings - the undergraduates' university students selected from two universities in Kwara State, Nigeria. They represent the participants in the study.

The informed consent of these participants (undergraduate students) was sought before administering the instrument developed for data collection in the study to them and they were assured of the confidentiality of the information they supplied. They were also assured that they retain the right to participate or not and even to opt-out at any point provided they were no more interested in the research. 


\section{REFERENCES}

Alan, M. (2016). Excess cellphone use may mean anxiety, depression. Retrieved from: http://www.webmd.com/ depression/news/20160315/could-too-much-cellphone-time-signal-anxiety-depression\#1

Augner, C., \& Hacker, G. W. (2012). Associations between problematic mobile phone use and psychological parameters in young adults. International Journal of Public Health, 57(2), 437-441. doi:10.1007/s00038-0110234-z PMID:21290162

Babbie, E. (2013). The basics of social research (6th ed.). Wadsworth Cengage Learning.

Bandura, A. (1997). Self-Efficacy: The Exercise of Control. Freeman \& Company.

Banjo, O., Hu, Y., \& Sundar, S. S. (2008). Cell Phone Usage and Social Interaction with Proximate Others: Ringing in a Theoretical Model. The Open Communication Journal, 2(1), 127-135. doi:10.2174/1874916X00802010127

Barkley, J. E., \& Lepp, A. (2013). Cellular telephone use is associated with greater sedentary behavior independent of leisure-time physical activity. Applied Physiology, Nutrition, and Metabolism, 38(S1), 1023.

Baumeister, R. F. (1997). Identity, self-concept and self-esteem: the self-lost and found. In R. Hogan, J. Johnson, \& A. Briggs (Eds.), Handbook of personality and psychology (pp. 681-710). Academic Press. doi:10.1016/ B978-012134645-4/50027-5

Baylor University. (2012). Cell phone addiction similar to compulsive buying and credit card misuse, experts say. Retrieved from: www.sciencedaily.com/releases/2012/11/121128122045.htm

Billieux, J. (2012). Problematic Use of the Mobile Phone: A Literature Review and a Pathways Model. Current Psychiatry Reviews, 8(4), 299-307. doi:10.2174/157340012803520522

Boase, J., \& Ling, R. (2013). Measuring mobile phone use: Self-report versus log data. Journal of ComputerMediated Communication, 18(4), 508-519. doi:10.1111/jcc4.12021

Brackett, L. K., \& Carr, B. N. Jr. (2001). Cyberspace advertising vs. other media: Consumer vs. mature student attitudes. Journal of Advertising Resources, 41(5), 23-32. doi:10.2501/JAR-41-5-23-32

Brody, C., Totomir, B., Sovannary, T., Pal, K., Mengsrum, S., \& Dionosio, J. (2017). Mobile phone use among female entertainment workers in Cambodia: An observation study. mHealth, 3(3), 1-12. doi:10.21037/ mhealth.2017.01.01 PMID:28293620

Bude.Com. (2014). Nigeria - Mobile Market - Insights, Statistics and Forecasts. Retrieved, from: https://www. budde.com.au/Research/Nigeria-Mobile-Market-Insights-Statistics-and-Forecasts.html

Butt, S., \& Phillips, J. G. (2008). Personality and self-reported mobile phone use. Computers in Human Behavior, 24(2), 346-360. doi:10.1016/j.chb.2007.01.019

Comulada, W. S., Swendeman, D., \& Ramanathan, N. (2018). Time series visualizations of mobile phone-based daily diary reports of stress, physical activity, and diet quality in mostly ethnic minority mothers: Feasibility study. JMIR Formative Research, 2(2), e11082. doi:10.2196/11062 PMID:30684407

Coopersmith, S. (1967). The antecedents of self-esteem. W. H. Freeman \& Co.

Coopersmith, S. (1989). Self-esteem inventories. Consulting Psychologists Press.

Creswell, J. W. (2014). Research Design, Qualitative, Quantitative and Mixed Methods Approaches. Sage.

Creswell, J. W., \& Creswell, J. D. (2017). Research design: Qualitative, quantitative, and mixed methods approaches. Sage Publications, Inc.

Creswell, J. W., \& Creswell, J. D. (2018). Research design: qualitative, quantitative \& mixed methods approaches. Sage Publications, Inc.

Chartterjee, S. (2014). A Sociological Outlook of Mobile Phone Use in Society. International Journal of Interdisciplinary and Multidisciplinary Studies, 1(6), 55-63.

Crocker, J., \& Wolfe, C. T. (2001). Contingencies of self-worth. Psychological Review, 20(4), 593-623. doi:10.1037/0033-295X.108.3.593 PMID:11488379 
Chou, C., \& Hsiao, M. C. (2000). Internet addiction, usage, gratification, and pleasure experience: The Taiwan college students' case. Computers \& Education, 35(1), 65-80. doi:10.1016/S0360-1315(00)00019-1

Chou, T.-J., \& Ting, C.-C. (2003). The role of flow experience in cyber-game addiction. Cyberpsychology \& Behavior, 6(6), 663-675. doi:10.1089/109493103322725469 PMID:14756934

deGournay, C. (2002). Pretense of intimacy in France. In J. E. Katz \& M. Aakhus (Eds.), Perpetual contact: Mobile communication, private talk, public performance (pp. 193-205). Cambridge University Press. doi:10.1017/ CBO9780511489471.015

Ehrenberg, A., Juckes, S., White, K. M., \& Walsh, S. P. (2008). Personality and self-esteem as predictors of young people's technology use. Cyberpsychology \& Behavior, 11(6), 739-741. doi:10.1089/cpb.2008.0030 PMID:18991531

Ezemenaka, E. (2013). The usage and impact of Internet enabled phones on academic concentration among students of tertiary institutions: A study at the University of Ibadan, Nigeria. International Journal of Education and Development Using Information and Communication Technology, 9(3), 162-173.

Fortunati, L., Lee, F., \& Lin, A. (2008). Introduction to the Special Issue on Mobile Societies in Asia-Pacific. International Journal: Information Society, 24(3), 135-139. doi:10.1080/01972240802019954

Gao, Y., Li, A., Zhu, T., Liu, X., \& Liu, X. (2016). How smartphone usage correlates with social anxiety and loneliness. PeerJ, 4, e2197. doi:10.7717/peerj.2197 PMID:27478700

Gunther, A. C., \& Thorson, E. (1992). Esther Thorson Perceived persuasive effects of product commercials and public service announcements- Third-person effects in new domains. Communication Research, 19(5), 574-596. doi:10.1177/009365092019005002

Gunther, A. C., \& Thorson, E. (1992). Perceived persuasive effects of product commercials and public service announcements: Third-person effects in new domains. Communication Research, 19(5), 574-596. doi:10.1177/009365092019005002

Hiscock, D. (2004). Cell phones in class - This, too, shall pass? Community College Week, 16, 4-5.

Höflich, J.R. \& Rössler, P. (2001). Mobile schriftliche Kommunikationoder: E-mail fur das Handy. Medien and Kommunikationswissenschaft, 49, 437-461.

Hoffman, D. L., \& Novak, T. P. (1996). Marketing in Hypermedia Computer-Mediated Environments: Conceptual Foundations. Journal of Marketing, 60(3), 50-68. doi:10.2307/1251841

Hong, F., Chiu, S., \& Huang, D. (2012). A model of the relationship between psychological characteristics, mobile phone addiction and use of mobile phones by Taiwanese university female students. Computers in Human Behaviour, 28, 2152-2159.

Hu, F., \& Liu, Y. (2011). An Empirical Examination on Mobile Services Adoption in Rural China. JDCTA, 5(1), 328-334. doi:10.4156/jdcta.vol5.issue 1.35

Ictech, O. B. II. (2014). Smartphones and Face-to-Face Interactions: Extending Goffman to 21st Century Conversation. University of New Orleans Theses and Dissertations. Paper 1812.

Jean, B., \& Park, N. (2012). Mobile voice communication and loneliness: Cell phone use and the social skills deficit hypothesis. New Media \& Society, 15(7), 1094-1111. doi:10.1177/1461444812466715

Ken State University. (2011). Attachment to cellphones more about entertainment, less about communication. Retrieved from: https://www.sciencedaily.com/releases/2011/06/110628113139.htm

Kothari, C. R. (2013). Research methodology: Theory and Techniques (2nd Revised Edition). New Age, Publishers.

Kwon, M., Lee, J.-Y., Won, W.-Y., Park, J.-W., Min, J.-A., Hahn, C., Gu, X., Choi, J.-H., \& Kim, D.-J. (2013). Development and Validation of a Smartphone Addiction Scale (SAS). PLoS One, 8(2), e56936. doi:10.1371/ journal.pone.0056936 PMID:23468893 
Lee, C. C., Hsieh, M. C., \& Huang, H. C. (2011). The Influence of Mobile Self-efficacy on Attitude towards Mobile Advertising. Advances in Information Sciences and Service Science, 3(3), 100-108. doi:10.4156/aiss. vol3.issue 3.13

Lenhart, A., Ling, R., Campbell, S., \& Purcell, K. (2010). Teens and mobile phones. Pew Internet and American Life Project, 20, 1-94.

Lepp, A., Barkley, J. E., \& Karpinski, A. C. (2015). The relationship between cell phone use, academic performance, anxiety, and Satisfaction with Life in college students. Computers in Human Behavior, 31, 343-350. doi:10.1016/j.chb.2013.10.049

Lloyd, K., \& Devine, P. (2009). The Net Generation. Access Research Knowledge No 62.

Marlatt, A. G., Baer, J. S., Donovan, D. M., \& Kivlahan, D. R. (1988). Addictive behaviours: Etiology and treatment. Annual Review of Psychology, 39(1), 223-252. doi:10.1146/annurev.ps.39.020188.001255 PMID:3278676

Matic, A., Osmani, V., \& Mayora-Ibarra, O. (2012). Analysis of social interactions through mobile phones. Mobile Network Application. Retrieved from: https://venetosmani.com/publications/Analysis_of_Social_Interactions_ Through_Mobile_Phones.pdf

McQuail, D. (1983). Mass Communication Theory: An Introduction. Sage Publications, UK.

North, D., Johnston, K., \& Ophoff, J. (2014). The use of mobile phones by South African university students. Issues in Informing Science and Information Technology, 11, 115-138. Retrieved from http://iisit.org/Vol11/ IISITv11p115-138North0469.pdf

Perlow, L. A. (2012). Sleeping with your smartphone: How to break the 24/7 habit and change the way you work. Harvard Business Press.

Pundir, P., Andrew, T., Binu, V. S., \& Kamath, R. (2016). Association of problematic mobile phone use with psychological distress and self-esteem among college students in South India: A cross-sectional study. International Journal of Community Medicine and Public Health, 3(10), 2841-2849. doi:10.18203/2394-6040. ijcmph20163371

Rainie, L., \& Zickuhr, K. (2015). Phone use in social gatherings. Pew Research Center. Retrieved from: https:// www.pewinternet.org/2015/08/26/chapter-4-phone-use-in-social-gatherings/\#

Roos, J. P. (2003). Sociology of Cellular telephone: The Nordic Model. Telecommunications Policy, 17(6), 446-456. doi:10.1016/0308-5961(93)90015-U

Rosenberg, M. (1965). Society and the adolescent self-image. Princeton University Press. doi:10.1515/9781400876136

Selwyn, N. (2003). Schooling the mobile generation: The future for schools in the mobile networked society. Brock Journal of Education, 24(2), 131-144.

Silk, J. B., Beehner, J. C., Bergman, T. J., Crockford, C., Engh, A. L., \& Moscovice, L. R. (2009). The benefits of social capital: close social bonds among female baboons enhance of spring survival. Proceedings of The Royal Society B-Biological Sciences, 276(1670), 3099-3104. doi:10.1098/rspb.2009.0681

South Africa Good News. (2005). Vodacom offers cheapest peak-time call tariffs in world. Retrieved from: http://www.sagoodnews.co.za/search/communication/477155.htm

Srinivas, P., \& Faiola, A. (2014). Smartphone Dependency and Consciousness: Observing Flow in the Everyday Life. Retrieved from:http://research.iupui.edu/events/researchday2014/documents/b48.pdf

Srivastava, L. (2005). Mobile phones and the evolution of social behaviour. Behaviour \& Information Technology, 24(2), 111-129. doi:10.1080/01449290512331321910

The World Unplugged Project. (2019). Going 24 Hours without media. Retrieved from: https://icmpa.umd.edu/ portfolio/the-world-unplugged/

Thomee, S., Harenstam, A., \& Hagberg, M. (2011). Mobile phone use and stress, sleep disturbances, and symptoms of depression among young adults - A prospective cohort study. BMC Public Health, 11(1), 66-76. doi:10.1186/1471-2458-11-66 PMID:21281471 
Tsang, M. M., Ho, C. H., \& Liang, T. P. (2004). Consumer Attitudes toward Mobile Advertising: An Empirical Study. Retrieved from http://www.ecrc.nsysu.edu.tw/liang/paper/17Mobile\%20advertising\%20(IJEC\%202004). pdf

Walsh, S. P., White, K. M., Hyde, M. K., \& Watson, B. (2008). Dialling and driving: Factors influencing intentions to use a mobile phone while driving. Accident; Analysis and Prevention, 40(6), 1893-1900. doi:10.1016/j. aap.2008.07.005 PMID:19068291

Walsh, S. P., White, K. M., \& Young, R. M. (2010). Needing to connect: The impact of self and others on young people's involvement with their mobile phone. Australian Journal of Psychology, 62(4), 194-203. doi:10.1080/00049530903567229

Whiteside, S. P., \& Lynam, D. R. (2001). The five factor model and impulsivity: Using a structural model of personality to understand impulsivity. Personality and Individual Differences, 30(4), 669-689. doi:10.1016/ S0191-8869(00)00064-7

Yang, Y., Yen, J., Hung, C., Cheng, C., \& Yen, C. (2010). The association between problematic cellular phone use and risky behaviours and low self-esteem among Taiwanese adolescents. BMC Public Health, 10(217), 1-8.

Youth Action \& Policy Association. (2004). Phone bills putting under 18s in serious debt. Retrieved from: https://www.smh.com.au/articles/2004/07/17/1089694607927.html

Tella Adeyinka is now an Assistant Professor in the Department of Library and Information Science, Faculty of Communication and Information Sciences, University of Ilorin, Nigeria, and a Visiting Researcher in the Department of Information Science, University of South Africa in Pretoria, South Africa. Tella attended St. Andrews College of Education, Oyo between 1989-92, where he obtained NCE certificate which qualifies him as a professional teacher. He later gained direct entry admission to the most prestigious university in Nigeria i.e. The University of Ibadan where He obtained his Bachelor Degree Certificate in Guidance and Counselling/Political Science and graduate with a Second Class Honour, Upper Division. After his Youth Core in the year 2000, Tella enrolled for master degree in Counselling Psychology in the same University of Ibadan and finished in 2001. He enrolled for another Master Degree programme in Library and Information Studies and finished in 2004. Tella returned to Counselling Psychology to commence a Ph.D. degree in Test, Measurement and Evaluation. He was about presenting His proposal for the Ph.D. when the result of the Commonwealth Scholarship which he early applied for was released. Eventually, he won the Commonwealth Scholarship to Study Library and Information Science at the University of Botswana in Gaborone in Oct, 2005 and finished in Sept. 29th, 2009. Tella was rated number 28 of scientists in Nigeria and number 1 in his University in the ranking of scientist in Nigeria released by Webometrics (Web of Science and Google) in March, 2015; and currently No 35 in Nigeria. In 2007, he was awarded small grant for thesis writing for the Ph.D. students' category by the council for the development of social science research in Africa (CODESRIA). He has written and published articles mostly in International reputable refereed journals together with chapters in books. He is an editorial member/reviewer of many Web of Science LIS journals. Currently, he is the Associate Editor International Journal of Library and Information Science, former Editor-in-Chief- International Journal of Information Processing and Communication (IJIPC) and currently Editor-in-Chief Unilorin International Journal of Library and Information Science. His research areas include e-learning, information literacy, information communication technology, psychology of information, research methodology in library and information science and information ethics, etc. Tella is an external examiner for LIS Ph.D. candidates in Babcock University, and University of Ibadan, Nigeria, University of Fort Hare, University of Zululand, University of South-Africa and University of KwaZulu-Natal in South Africa and University of Zambia in Lusaka. He was awarded a Visiting Research Fellow by the Department of Information Science, University of South Africa (UNISA) in Pretoria South Africa in 2016 for three years period - 2016-2018. And now a Visiting Researcher to the same Dept. beginning from 2019. In January 2016, Tella was declared the winner of the prestigious Dr. T.M. Salisu award for the Most Published Librarian for the year 2015 by the Nigerian Library Association. Dr. Tella has again in February 2018 won the 2017 Most Published Librarian, the same award by the Nigerian Library Association. Dr. Tella has visited Countries such as: United State of America Italy Portugal, United Arab Emirate- Abu-Dhabi Qatar South Africa Botswana Zimbabwe Zambia Kenya, Cote D'voire Togo, and Republic of Benin. Currently, Dr. Tella has published 190 academic papers mostly in Web of Science/Schimago ranked journals, edited conference proceedings and chapters in books. In addition, he has edited six information Science reference texts. 